\title{
Struktur dan Nilai Karakter Film Animasi Anak "Diva the Series" Karya Kastari Animation
}

\author{
T. Rizkia Arnolia ${ }^{1 *}$, Mohammad Kanzunnudin², Lintang Kironoratri ${ }^{3}$ \\ 1,2,3 Pendidikan Guru Sekolah Dasar, Universitas Muria Kudus, \\ Kudus, Indonesia \\ *Email: arnoliatita@gmail.com
}

\begin{abstract}
Banyak orang yang mulai melupakan nilai-nilai budaya bangsanya, perilaku dan gaya hidup yang tidak berpedoman pada adat ketimuran, dan semakin lunturnya budi pekerti dalam kehidupan bermasyarakat. Penelitian ini bertujuan untuk menganalisis struktur dan nilai karakter yang terdapat dalam film animasi Diva The Series karya Kastari Animation. Jenis penelitian yang digunakan yakni penelitian kualitatif dengan pendekatan deskriptif. Teknik analisis yang digunakan dalam penelitian ini merupakan analisis struktur yang dikemukakan oleh Stanton. Teknik pengumpulan data dalam penelitian ini menggunakan teknik dokumentasi yang bersumber pada data yang valid untuk kemudian dianalisis menggunakan kartu data. Hasil penelitian dalam film Diva The Series memuat 5 struktur cerita yang meliputi alur, penokohan, latar, tema, amanat dan 5 nilai karakter yakni karakter religius dalam episode "Pergi Tadarus", karakter nasionalisme dalam episode "Hari Kartini", karakter kemandirian dalam episode "Belajar Jualan", karakter gotong royong dalam episode "Masjid dan Pemuda Punk", dan karakter integritas dalam episode "Jujur Itu Keren". Implikasi penelitiannya diharapkan dapat memberikan dampak positif bagi para penontonnya khususnya anak-anak.
\end{abstract}

Kata Kunci: Nilai karakter, Film Animasi

\begin{abstract}
Many people are starting to forget the cultural values of their nation, behavior and lifestyles that are not guided by eastern customs, and the decline of character in social life. This study aims to analyze the structure and character values contained in the animated film Diva The Series by Kastari Animation. The type of research used is qualitative research with a descriptive approach. The analytical technique used in this research is the structural analysis proposed by Stanton. Data collection techniques in this study used documentation techniques sourced from valid data and then analyzed using data cards. The results of the research in the Diva The Series film contain 5 story structures which include plot, characterization, setting, theme, mandate and 5 character values, namely religious characters in the episode "Pergi Tadarus", the character of nationalism in the episode "Kartini Day", the character of independence in the episode "Learning to Sell", the character of mutual cooperation in the episode "Masjid and Pemuda Punk", and the character of integrity in the episode "Honest is Cool". The implications of the research are expected to have a positive impact on the audience, especially children.
\end{abstract}

Keywords: Character values, Animated Movies

\section{PENDAHULUAN}

Pendidikan merupakan salah satu hal yang utama dalam kehidupan, melalui pendidikan kualitas hidup manusia akan naik ke tingkat yang lebih tinggi (Dwi pradipta, 2017; Rachmawati et al., 2018). Pendidikan digunakan sebagai suatu cara yang dilakukan untuk membentuk kepribadian sesuai dengan nilai-nilai moral bangsa agar sesuai dengan tujuan bangsa Indonesia (Ramdani, 2018; We \& Fauziah, 2020). Pendidikan dapat dilakukan kapanpun dan di manapun tidak terbatas ruang dan waktu. Pendidikan selaku upaya untuk mengubah prilaku anak menjadi lebih baik, peling utama dalam mengajarkan nilai karakter (Hidayah, 2015; Pasrah et al., 2020). Pendidikan yang mengimplementasikan nilai-nilai karakter adalah salah satu upaya membentuk

${ }^{*}$ Corresponding author.

Received February 09, 2021; Accepted March 14, 2021; Available online April 25, 2021

(C) 2020 IVCEJ. All Rights Reserved

Indonesian Values and Character Education Journal (IVCEJ) | 20 
manusia secara utuh (holistik) yang berkarakter (Putry, 2019; Utomo \& Muntholib, 2018). Manusia yang berkarakter adalah manusia yang mampu mengembangkan aspek fisik, emosi, sosial, kreativitas, spiritual, dan intelektual secara optimal (Utomo \& Muntholib, 2018; Yuniarni, 2016). Konsep pendidikan karakter tersebut harus diintegrasikan ke dalam kurikulum (Christopher et al., 2019). Hal ini tidak berarti bahwa pendidikan karakter akan diterapkan secara teoretis, tetapi menjadi penguat kurikulum yang sudah ada, yaitu dengan mengimplementasikan dalam mata pelajaran dan keseharian peserta didik. Salah satu upaya yang bisa dilakukan adalah dengan mengintegrasikan bahan ajar yang digunakan dalam kegiatan pembelajaran dengan nilai-nilai karakter. Salah satu masalah yang sering ditemui dalam dunia pendidikan yakni rendahnya nilai karakter di Indonesia (Chairiyah, 2017; Hidayah, 2015). Banyak orang yang mulai melupakan nilai-nilai budaya bangsanya, perilaku dan gaya hidup yang tidak berpedoman pada adat ketimuran, dan semakin lunturnya budi pekerti dalam kehidupan bermasyarakat (Khusniati, 2014; Tanto et al., 2019). Misalnya: kurang sopan terhadap orang yang lebih tua, berpakaian yang tidak sesuai dengan adat budaya ketimuran, rendahnya nilai kejujuran yang dimiliki oleh anak bangsa, tidak melestarikan adat dan budaya daerah setempat, tawuran, dan banyak anak yang sering menonton film dewasa yang dapat menyebabkan pola pikir anak menjadi berubah dan akhirnya melakukan hal-hal yang di luar batas. Beberapa faktor diatas dapat dipengaruhi oleh faktor internal dari anak itu sendiri maupun faktor eksternal yang berasal dari lingkungan sekitar.

Hal yang perlu dilakukan untuk mengatasi lemahnya nilai karakter yakni dengan memberikan pendidikan karakter pada anak sejak dini. Penanaman pendidikan karakter biasanya diterapkan dalam tingat pendidikan formal seperti sekolah maupun dalam lingkup keluarga. Selain itu, pendidikan karakter juga dapat ditemukan dalam sebuah film animasi yang dapat ditemukan melalui media televisi maupun aplikasi media sosial yang bernama youtube. Lemahnya pendidikan karakter dapat di atasi melalui hal-hal yang menarik dan banyak digemari oleh anak-anak. Salah satunya melalui sebuah tontonan film animasi anak yang mengandung nilai pendidikan karakter (Sayekti, 2019). Banyak anak yang gemar menonton tayangan film animasi di media elektronik televisi seperti film animasi Upin Ipin, Adit dan Sopo Jarwo, Nusa dan Rara, dan masih banyak lagi (Putri et al., 2021; Sayekti, 2019). Tidak dapat dipungkiri bahwa dunia pertelevisian mempunyai peranan yang penting bagi perkembangan anak-anak. Anak akan mudah meniru apa saja yang ia lihat, mereka akan mencontoh perilaku yang dilakukan orang disekitarnya atau berdasarkan tayangan yang ia lihat. Maka dari itu, orang tua juga mempunyai peran yang penting dalam mengarahkan anak pada tayangan yang mampu membentuk karakter anak sejak dini. Melalui tayangan film yang berkualitas dan sesuai dengan umurnya, maka anak akan belajar untuk memahami nilai karakter yang harus ditanamkan dalam dirinya sebagai pedoman hidupnya kelak.

Indonesia sekarang telah memasuki era digital. Sebuah era yang memudahkan masyarakat dalam memperoleh informasi secara cepat dan akurat. Selain melalui media televisi, tayangan film animasi anak juga dapat disaksikan melalui aplikasi youtube. Tidak dapat dipungkiri bahwa pada zaman sekarang banyak anak yang menghabiskan waktunya untuk bermain gawai, hal ini tentunya dapat membantu anak untuk menanamkan nilai karakter sejak dini melalui tontonan film animasi anak yang mengandung nilai pendidikan (Munawaroh \& Prasetyo, 2019; Pasrah et al., 2020). Orang tua harus dapat membimbing dan mengawasi anak mengenai aktivitas yang dilakukannya. Aplikasi youtube merupakan salah satu wujud dari perkembangan zaman yang semakin canggih. Youtube merupakan suatu situs sebagai media berbagi video untuk menyebarkan berbagai informasi dan hiburan (Mansyur, 2020). Aplikasi ini berisi berbagai macam video, berita, musik yang dikemas secara menarik agar dapat dinikmati oleh semua orang. Hal ini dapat membantu mempermudah seseorang dalam menemukan informasi. Namun, kita sebagai pengguna harus dapat menyaring informasi yang diterima agar informasi tersebut dapat memberikan manfaat bagi para penikmatnya.

Temuan ini didukung dengan penelitian sebelumnya yang menyatakan film animasi "Horton Hears a Who" masih dapat tonton dan digunakan sebagai media penanaman nilai karakter pada siswa dengan bimbingan guru atau orang tua (Munawaroh \& Prasetyo, 2019). Film animasi Nussa dan Rara episode Baik itu Mudah memuat enam nilai karakter (Sayekti, 2019). Film animasi Upin dan Ipin ditampilkan bahwa setiap episode mengandung nilai karakter baik (Putri et al., 2021). Film animasi cocok digunakan sebagai media untuk menyampaikan edukasi dan pesan moral serta nilai-nilai karakter kepada anak usia sekolah dasar. Selain nilai karakter, memahami sebuah struktur teks dalam sebuah karya sastra juga merupakan hal yang penting. Unsur intrinsik yang terkandung dalam sebuah karya sastra juga penting. Hal tersebut meliputi alur, tokoh, karakter, latar, tema, dan amanat. Penelitian ini bertujuan untuk menganalisis struktur dan nilai karakter dalam film animasi Anak Diva The Series Karya Kastari Animation" yang 
ditayangkan melalui aplikasi Youtube. Penelitian ini diharapkan dapat memberikan dampak positif bagi para penontonnya khususnya anak-anak.

\section{METODE}

Pendekatan yang digunakan dalam penelitian ini adalah pendekatan kualitatif. Penelitian kualitatif adalah jenis penelitian yang temuan-temuannya tidak diperoleh melalui prosedur kuantifikasi, perhitungan statistik, atau bentuk cara-cara lainnya yang menggunakan ukuran angka. Penelitian kualitatif deskriptif dilakukan untuk menganalisis dan mendeskripsikan secara lebih jelas dan akurat mengenai struktur dan nilai karakter dalam film animasi Diva The Series Karya Kastari Animation. Sumber data primer diperoleh melalui channel Youtube Diva The Series yang berisi mengenai video-video film animasi yang mengandung nilai karakter. Kemudian, sumber data sekunder diperoleh melalui jurnal, blog, dan artikel yang berkaitan dengan masalah yang dibahas dalam penelitian ini. Teknik pengumpulan data yang digunakan dalam penelitian ini yakni teknik dokumentasi. Dokumentasi ditujukan untuk memperoleh data langsung dari tempat penelitian meliputi buku-buku yang relevan, peraturan-peraturan, laporan kegiatan, fotofoto, film dokumenter dan data yang relevan. Dokumentasi yang digunakan dalam penelitian ini dilakukan dengan cara menonton dan mengamati dialog serta adegan dalam film untuk menemukan mengenai struktur dan nilai karkater film animasi Diva The Series. Mencatat hal-hal penting yang ada dalam film untuk kemudian dianalisis kembali ke dalam sebuah kartu data. Setiap penelitian membutuhkan sebuah metode, teknik analisis, dan teori yang mendukung keberhasilan sebuah penelitian. Maka dari itu, penelitian ini akan menggunakan metode Miles dan Hubermen yakni reduksi data, penyajian data, dan menarik kesimpulan. Mereduksi data berarti mengumpulkan data atau hal-hal penting sesuai tujuan penelitian untuk mendapatkan informasi yang valid. Kedua yakni tahap menyajkan data, setelah direduksi maka data yang diperoleh akan dianalisis dalam bentuk teks naratif dan data dokumentasi. Tahap ketiga yakni penarikan kesimpulan, data yang sudah dianalisis berdasarkan bukti yang mendukung penelitian kemudian disimpulkan secara jelas dan akurat.

\section{HASIL DAN PEMBAHASAN}

Hasil

Karya sastra adalah suatu mahakarya indah yang diciptakan pengarang untuk memberikan informasi mengenai isi cerita. Karya sastra merupakan karya imajinatif yang berupa tulisan atau bahasa yang indah, menghibur, serta dapat sesuai dengan pengalaman penciptanya. Struktur cerita adalah bagian dari susunan cerita yang tidak dapat dipisahkan. Struktur cerita yang akan digunakan dalam penelitian ini merujuk pada teori struktur yang dikemukakan oleh Stanton (2012:26) yang mengungkapkan bahwa unsur intrinsik dalam karya sastra terdiri dari alur, karakter (penokohan), latar, tema, dan sarana sastra (amanat). Pendidikan karakter adalah ikhwal karakter/pendidikan yang mengajarkan haekat karakter/pendidikan yang mengajarkan hakekat karakter dalam ketiga ranah yaitu cipta, rasa, dan karsa atau pemikiran, perasaan, dan perilaku. Pendidikan karakter merupakan suatu upaya yang dilakukan untuk membentuk suatu karakter sebagai pedoman untuk menghadapi kehidupan di masa yang akan datang. Penelitian ini akan merujuk pada Permendikbud No. 20 tahun 2018 pasal 2 ayat 2 yang berbunyi:" Nilai sebagaimana dimaksud pada ayat (1) merupakan perwujudan dari 5 (lima) nilai utama yang saling berkaitan yakni religiusitas, nasionalisme, kemandirian, gotong royong, dan integritas yang terintegrasi dalam kurikulum.

Tema film animasi diva the series, tema merupakan unsur yang mendasari suatu cerita. Tema yang mendasari film animasi Diva The Series ini adalah tema persahabatan. Film animasi Diva The Series ini menceritakan mengenai persahabatan antara Diva, Mona, feby, Tomi, dan Putu. Mereka adalah teman akrab dan tempat tinggal mereka juga berdekatan. Walaupun mereka berasal dari latar belakang yang berbeda-beda, namun itu semua tidak membuat mereka lantas membeda-bedakan satu sama lain. Mereka selalu kompak dalam kondisi apapun. Setiap episode-episode yang ditayangkan selalu menggambarkan mengenai kekompakan persahabatan mereka yang tentunya sedikit dibumbui dengan pertengkaran-pertengakaran kecil yang membuat film animasi Diva The Series semakin menarik untuk dinikmati. Tokoh utama atau tokoh sentral adalah tokoh yang sering muncul atau mempunyai pengaruh besar dalam sebuah ceita. Diva sebagai tokoh utama mempunyai watak yang sederhana, kreatif, dan bijaksana. Hal ini dapat dilihat dalam petikan dialog " Riasannya nggak perlu ke salon di rias sederhana saja bu." Hal ini dapat dimaknai bahwa Diva berwatak sederhana. "Diva mau jualan aksesoris saja." 
Hal ini dapat disimpulkan bahwa Diva berwatak kreatif. "Mon, aku sih nggak apa-apa bonusnya kamu makan. Tapi kata bu guru jujur itu keren" dalam hal ini Diva mempunyai watak bijaksana. Feby mempunyai watak yang kreatif dan peduli terhadap orang lain. Hal ini dapat diperkuat dalam cuplikan dialog " Beta pintar menggambar ma." Hal ini dapat dimaknai bahwa Feby mempunyai bakat menggambar dan dapat dimanfaatkan untuk belajar jualan di sekolah. Selanjutnya dalam dialog “Diva, Mona ketinggalan." Ini berarti Feby mempunyai sifat peduli terhadap orang lain.

Dalam serial Diva The series Mona mempunyai watak yang kurang jujur dan kurang pandai dalam mengelola keuangan. Hal ini terlihat dalam dialog "Gratisannya buat akua aja ah, Diva dan Feby paling juga nggak tau." Ini dapat diartikan bahwa Mona mempunyai sifat yang kurang jujur. Sifat Mona selanjutnya terlihat dalam dialog "Eh anu, donatnya udah aku habisin." Dalam hal ini Mona kurang pandai mengelola keuangan karena dagangan yang digunakan untuk berjualan donat malah dimakan sendirisehingga tidak untung malah rugi. Tomi mempunyai watak yang malas dan gegabah. Hal ini dapat dilihat dalam cuplikan adegan " Aku ngantuk mau tidur aja habis ini, aku nggak ikut tadarus." Hal ini dapat dimaknai bahwa Tomi mempunyai watak pemalas. Selanjutnya, dapat dilihat dalam cuplikan dialog "Wah gawat nih anak punk pasti mau ngerusuhin masjid." Hal ini menunjukkan bahwa Tomi bersikap gegabah dalam menyimpulkan segala sesuatu. Putu mempunyai watak kurang bisa menghargai perbedaan namun terkadang juga sering memberikan saran kepada temannya. Hal ini dapat dilihat dalam cuplikan dialog "Kita beli es krim di tempat Babe yuk. Kita berdua aja yang lainnya an lagi puasa." Di sini terlihat bahwa Putu kurang menghargai temannya yang sedang menjalankan ibadah puasa.watak Putu selanjutnya dapat dilihat dalam cuplikan dialog “ Nanti minta aja nggak apa-apa kok." Dalam cuplikan tersebut terlihat Putu sedang memberikan saran kepada Feby dan Mona untuk meminta bonus kepada Babe karena mungkin babe lupa.

Tokoh tambahan adalah tokoh yang kemunculan hanya sesekali atau bebera kali dalam sebuah cerita. Tokoh tambahan adalah tokoh pendukung dalam sebuah cerita atau karya sastra. Tokoh Pupus adalah hewan peliharaan kesayangan Diva yang memiliki sifat setia dan selalu membantu Diva. Hal ini dapat dilihat dalam cuplikan dialog "Bagaimana kalau jualan puding." Pupus memberikan ide jualan kepada Diva untuk berjualan puding di sekolah. Dari cuplikan tersebut dapat diketahui Pupus memiliki sifat yang selalu membantu majikan kesayangannya. Dalam film animasi Diva The Series di jelaskan bahwa ibu guru mempunyai watak yang sabar dan mengayomi anak didiknya. Hal ini ditunjukkan dalam cuplikan dialog "Boleh, tidak harus makanan kok yang penting kalian harus bisa menetapkan harga jual dengan baik, jangan sampai rugi." Dalam dialog tersebut dijelaskan bahwa berjualan tidak harus makanan namun boleh apa saja yang penting tidak rugi. Ibu guru sangat menghargai pendapat keinginan anak didiknya. Ibu diva mempunyai watak yang bijak dan solutif. Hal ini dapat dilihat dalam cuplikan kalimat " Bagaimana kalau jualan kalung, gelang, gantungan kunci?” Ibu Diva memberikan solusi ide jualan kepada Diva yang sempat kebingungan. Ibu Diva mempunyai watak yang bijaksana dan solutif. Babe mempunyai jiwa toleransi yang tinggi terhadap sesamanya. Hal ini terlihat dalam cuplikan adegan "Bukannya Babe nggak buth duit. Tapi selama Bulan Ramadhan Babe nggak jualan." Hal ini berarti Babe sangat menghormati para umat muslim yang menjalankan ibadah puasa dengan tidak berjualan selama bulan ramadhan. Om ucok mempunyai karakter yang suka menolong sesamanya yang membutuhkan bantuan. Hal ini dapat dilihat dalam dialog "Om Ucok walaupun bukan muslim tapi aku yakin banget kalau om Ucok pasti akan bantu." Dapat disimpulkan bahwa Om Ucok yang beragama non muslim bersedia menolong tanpa membedabedakan agama dan lain-lain.

Alur yang digunakan dalam film animasi Diva The Series merupakan alur lurus atau alur maju. Karena cerita ini tersusun secara berurutan sesuai kronologi ceritanya. Berikut merupakan salah satu contoh masalah yakni ketika Tomi mencurigai para anak punk yang berada di masjid akan membuat kerusuhan. Kemudian Tomi menghampiri teman-temannya dan meminta tolong kepada Um Ucok untuk membantu mengetahui kejadian yang sebenarnya. Mereka akhirnya menghampiri para anak punk tersebut dan mengetahui bahwa anak punk tersebut sedang gotong royong membersihkan masjid. Alur cerita terdiri dari pelukisan awal cerita, pertikaian awal cerita, klimaks, dan penyelesaian. Latar tempat yang ditampilkan dalam episode Pergi Tadarus berada di warung Babe dan masjid. Hal ini dapat dilihat dalam cuplikan dialog "Babe aku mau beli." Diceritakan bahwa Putu dan Feby ingin membeli makanan di warung Babe. Latar tempat selanjutnya berada di masjid. Berikut cuplikan dialog yang menunjukkan latar tempat "Habis Diva, aku ya yang ngaji." Dalam kalimat "Aku ya yang ngaji" dapat dimaknai bahwa mereka sedang berada di masjid untuk melaksanakan tadarus. Latar waktu yang dalam episode Pergi Tadarus berlangsung pada sore hari. hal ini terbukti dalam dialog "Ini kan udah sore mendingan kalian 
cepat mandi sana terus pergi tadarus ke masjid." Dalam cuplikan tersebut dapat dimaknai bahwa latar waktu terjadi pada sore hari saat Diva dan teman-temannya selesai bermain, Babe mengingatkan mereka untuk pulang dan pergi bertadarus di masjid.

Latar suasana yang terjadi dalam episode Pergi Tadarus adalah suasana keecewaan. Hal ini dapat ditemukan dalam cuplikan dialog "Yah...padahal beta pengen beli Be." Pada bulan Ramadhan Babe tidak berjualan karena menghormati umat muslim. Amanat yang terkandung dalam film animasi Diva The Series episode Pergi Tadarus adalah kita harus selalu menghargai perbedaan yang ada di sekitar kita walaupun berbeda agama, ras, dan suku bangsa. Perbedaan keyakinan jangan membuat manusia lantas merasa berbeda dan paling benar, justru dengan perbedaan kita dapat tetap hidup berdampingan saling mengasihi satu sama lain. Setiap ibadah yang kita lakukan harus didasarkan karena Tuhan bukan hanya untuk mendapatkan imbalan semata. (https://youtu.be/PwOVb5oTa20). Latar tempat yang ditampilkan dalam episode Hari Kartini yakni berada di Rumah Mona, Diva dan di sekolah. Hal ini terbukti dalam cuplikan dialog "Loh kok sudah pulang, ibu kan baru mau nonton pawainya." Pada dialog tersebut dapat isimpulkan bahwa latar tempat berada di rumah Mona. Latar tempat selanjutnya berada di rumah Diva. Hal ini dapat dibuktikan dalam cuplikan dialog "pakai kebaya lagi? (sambil memasak di dapur) dalam kalimat "sambil memasak di dapur" dapat dimaknai bahwa Diva dan ibunya sedang mengobrol di dapur rumah Diva. Latar tempat yang terakhir berada di sekolah. Hal ini dapat dilihat dalam cuplikan dialog "diluruskan ya anak-anak barisannya." Ketika ibu guru meminta anak-anak meluruskan barisannya dapatdimaknai bahwa latar tempat terjadi di sekolah.

Latar waktu yang terjadi dalam episode Hari Kartini yakni pada pagi hari. hal ini dapat dilihat dalam dialog "Ayo baris yang rapi." Pada pagi hari lbu guru sedang membariskan anakanak untuk mengikuti karnaval Hari Kartini. Latar suasana yang ada dalam episode Hari Kartini adalah kegelisahan dan kepanikan. Hal ini terbukti dalam cuplikan dialog "Aduh Mona kebelet pipis. Duh...bu tolongin mona nggak tahan bu..." dari cuplikan tersebut dapat disimpulkan bahwa Mona panik karena sudah tidak tahan ingin buang air kecil. Amanat yang dapat kita ambil dari film animasi Diva The Series episode Hari Kartini adalah sebagai warga Indonesia kita harus tetap melestarikan kebudayaan daerah agar tidak luntur tergerus Zaman, menjunjung tinggi adat istiadat daerah dengan memperingati hari besar nasional dan menggunakan adat daerah serta menanamkan jiwa nasionalisme cinta tanah air (https://youtu.be/XMlrJDi5Wn4). Latar tempat pada episode belajar jualan berada di sekolah, Rumah Diva, dan Rumah Feby. Hal ini dapat dilihat dalam dialog "Anak-anak hari Senin minggu depan giliran kelompok 3 yang berjualan di sekolah." Dalam kalimat "di sekolah" dapat dimaknai bahwa latar tempat yang terjadi berada di sekolah. Selanjutnya latar tempat terjadi di rumah Diva, hal ini dapat dilihat dalam penggalan dialog berikut " aku lagi cari ide jualan Pus." Dalam kalimat " cari ide jualan pus" dapat dimaknai bahwa Diva sedang melamun memikirkan ide jualan hal ini dilakukan Diva ketika berada di rumah. Latar tempat yang terakhir berada di rumah feby, hal ini tercermin dalam cuplikan dialog "Beta sebaiknya jualan apa ma?" dalam kalimat "jualan apa ma?" dapat disimpulkan bahwa Feby sedang meminta saran jualan kepada ibunya. Setting tempat ini berlangsung di rumah Feby.

Latar waktu dalam episode berlangsung sekitar pukul 09.00 atau itirahat pertama di sekolah. Hal ini dapat dibuktikan pada cuplikan dialog "Nanti kita jualan pas istirahat pertama ya?". Latar suasana yang ditemukan dalam episode belajar jualan adalah suasana bahagia. Hal ini terlihat dalam cuplikan dialog "Wah terima kasih bu." Diva dan Feby sangat bahagia karena ibu guru telah memborong dagannya. Amanat yang ada dalam film animasi Diva The Series episode Belajar Jualan yakni Kemandirian perlu ditanamkan sejak dini sehingga kita tidak terusmenerus bergantung kepada orang lain. Bukan berarti tidak membutuhkan bantuan orang lain, namun belajar untuk bertanggung jawab terhadap diri sendiri. Seperti yang tercermin dalam episode Belajar Jualan, ibu guru memberikan pembelajaran mengenai kemandirian melalui prakter untuk belajar berjualan sesuai bakat dan minat yang mereka punya. Rezeki dapat datang dari mana saja asalkan kita mau berusaha. (https://youtu.be/DHBev4sxalA). Serial Diva The Series Episode "Masjid dan Pemuda Punk". Latar tempat yang ditampilkan dalam episode Masjid dan Pemuda Punk yakni berada di masjid. Hal ini dilihat dalam petikan dialog "Eh...anu sebenernya kami si sini bukan mau membuat rusuh kok. Justru kami di sini mau beres-beres masjid biar rapi dan bersih." Latar waktu yang terdapat dalam episode Masjid dan Pemuda Punk yakni pada sore hari. hal ini dapat dilihat dalm cuplikan dialog "Om akan siapkan buka bersama untuk kalian." Ha ini dapat dimakna bahwa latar waktu terjadi pada sore hari. Latar suasana yang ditemukan dalam episode Masjid dan Pemuda Punk yakni suasana mencengkeram dan ketakutan. Hal ini dibuktikan pada cuplikan dialog "Terus gimana dong, mereka anak punk loh aku takut." Terjadi sebuah ketakutan Diva dan kawan-kawan terhadap anak punk. Amanat yang terkandung dalam film animasi Diva The Series adalah jangan melihat seseorang hanya 
berdasarkan tampilan luarnya saja, bisa jadi orang yang menurut kita buruk adalah orang yang lebih baik dari kita. Jangan mudah percaya dengan perkataan orang lain sebelum mengetahui fakta yang sebenarnya. Gotong royong adalah perbuatan yang perlu untuk dilestarikan. Dengan gotong royong pekerjaan akan menjadi ringan dan cepat terselesaikan. (https://youtu.be/BbOi9RRhGzQ).

Serial Diva The Series Episode “Jujur Itu Keren”, latar tempat yang ditunjukkan pada episode Jujur Itu Keren yakni d warung Babe. Hal ini dapat dibuktikan dalm dialog "Be, beli kerupuk ketela 3 sama es krim?". Dalam kalimat "beli kerupuk ketela 3 sama es krim?" dimaknai bahwa latar tempat terjadi di warung Babe saat Mona membeli makanan dan minuman di warung Babe. Latar suasana yang ditampilkan dalam episode Jujur Itu Keren yakni suasana menegangkan. Hal ini terbukti dalam cuplikan adegan "Ehmm...teman-teman sebenarnya Babe udah ngasih bonusnya. Tapi aku sudah makan di jalan maaf ya teman-teman." Dalam cuplikan dialog tersebut menunjukkan suasana ketegangan dikarenakan mona telah berbuat bohong kepada teman-temannya. Amanat yang ada dalam film animasi Diva The Series episode Jujur Itu Keren adalah jadilah orang yang selalu jujur dalam keadaan apapun. Tanamkan kejujuran dalam diri kita sejak kecil. Karena kebohongan yang kita lakukan dapat merugikan orang lain. Kebohongan yang dilakukan terus menerus akan berubah menjadi suatu watak yang sulit untuk dihilangkan. Jadilah orag yang jujur walaupun tidak mudah. (https://youtu.be/WQEcsh2eUI4)

Nilai karakter religius pada episode "Pergi Tadarus"(https://youtu.be/PwOVb5oTa20). Berdasarkan cuplikan film, Babe mengingatkan Diva dan teman-temannya untuk pergi tadarus di masjid sambil mengisi waktu luang menunggu waktu berbuka puasa. Akhirnya setelah bersiapsiap, Diva dan teman-temannya yang muslim bergegas untuk pergi tadarus ke masjid. Dialog di atas menunjukkan bahwa film animasi Diva The series mengandung nilai karakter religius. Hal ini diperoleh melalui sikap Diva dan teman-temannya yang menjalankan ibadah puasa dan pergi tadarus di masjid. Karakter religius adalah nilai karakter dalam diri seseorang yang berasal dari ajaran agama yang dianut dan bernilai ketuhanan, dan dalam perwujudannya berupa pikiran, perkataan, dan tindakan sebagai ibadah baik terhadap Tuhan Yang Maha Esa, sesama manusia dan alam sekitar (Rosikum, 2018). Karakter religius merupakan karakter paling penting dan utama yang dimiliki manusia terhadap Tuhannya. Dian dan Didkik (2017) menjelaskan bahwa niali religius merupakan salah satu nilai karakter yang dijadikan sebagai sikap dan perilaku yang patuh dalam melaksanakan ajaran agama yang dianut, toleran terhadap pelaksanaan agama lain, dan hidup rukun dengan pemeluk agama lain. Toleransi terhadap agama lain juga merupakan suatu bentuk nilai religius yang harus ditanamkan agar manusia dapat hidup berdampingan satu sama lainnya dengan saling mengasihi dan menyayangi. Hal ini diperkuat oleh Ahsanulhaq (2019) yang menjelaskan bahwa pembentukan karakter religius merupakan hasil usaha dalam mendidik dan melatih dengan sungguh-sungguh terhadap berbagai potensi rohaniah yang terdapat dalam diri manusia khususnya para peserta didik.

Nilai karakter Nasionalisme pada episode "Hari Kartini" (https://youtu.be/XMIrJDi5Wn4). Cuplikan adegan film animasi menceritakan mengenai Diva yang meminta izin ibunya untuk mengikuti karnaval peringatan Hari Kartini di sekolah. Dalam acara tersebut seluruh siswa diharapkan untuk memakai kebaya sebagai salah satu upaya untuk melestarikan kebudayaan di Indonesia. Dalam cuplikan adegan di atas ditunjukkan nilai karakter nasionalisme. Karakter jiwa nasionalisme harus mulai ditanamkan sejak dini sebagai bentuk kecintaan seseorang terhadap bangsa dan negaranya. Hal ini diperkuat oleh Bakar, dkk (2018) yang menyatakan bahwa karakter nasionali adalah cara berpikir, bersikap, dan berbuat yang menunjukkan kesetiaan, kepedulian, dan penghargaan yang tinggi terhadap bahasa, lingkungan fisik, sosial, budaya, ekonomi, dan politik bangsa, menempatkan kepentingan bangsa dan negara di atas kepentingan diri dan kelompoknya. Karakter nasionalisme pada anak perlu diajarkan dan diperkenalkan, sebab karakter nasionalisme menjadi ujung tombak pendidikan karakter kebangsaan yang memiliki peranan utama untuk dapat meraih kemerdekaan, mempertahankannya dan mengisinya sehingga mampubersaing dengan bangsa lain.

$$
\text { Nilai karakter Kemandirian pada episode "Belajar Jualan" }
$$

(https://youtu.be/DHBev4sxalA). Cuplikan adegan animasi tersebut menggambarkan seorang guru yang sedang memberikan tugas kelompok berjualan di sekolah untuk melatih kemandirian sejak dini. Kelompok yang mendapatkan tugas giliran jualan minggu depan adalah kelompok Diva, Feby, dan Mona. Mereka sangat bersemangat untuk mengikuti praktek belajar jualan. Pada adegan tersebut terdapat nilai karakter kemandirian yang ditanamkan oleh ibu guru kepada anak didiknya. Kemandirian adalah proses untuk belajar bertanggung jawab terhadap diri sendiri dan berani mengambil keputusan tanpa pengaruh dari orang lain. Kemandirian merupakan suatu keadaan seseorang di mana seseorang berusaha berdiri sendiri dalam arti tidak bergantung pada 
orang lain dalam mengambil keputusan dan mampu melaksanakan tugas hidup dengan penuh tanggung jawab. Sikap mandiri yang sudah tertanam sejak dini akan melekat dalam diri seseorang dan akan menjadi suatu kebiasaan yang baik untuk kedepannya (Vykhrushch et al., 2020). Kemandirian merupakan sikap, perbuatan, dan perilaku yang akan membawa percaya diri akan kemampuannya dalam menghadapi suatu permasalahan dan tidak memiliki ketergantungan pada pihak lain (Ismayani, 2013; Tanto et al., 2019). Manusia yang mandiri adalah manusia yang tidak menggantungkan sesuatu dari orang lain namun bukan berarti tidak membutuhkan bantuan orang lain. Mereka hanya belajar untuk bertanggung jawab terhadap apa yang ia lakukan.

Nilai karakter gotong royong pada episode "Masjid dan Pemuda Punk" (https://youtu.be/BbOi9RRhGzQ).Cuplikan pada film tersebut menjelaskan mengenai kecurigaan Diva dan kawan-kawan kepada para gerombolan anak punk, mereka takut jika anak punk tersebut ingin membuat kerusuhan di masjid. Namun setelah di konfirmasi ternyata para gerombolan anak punk tersebut sedang gotong royong untuk membersihkan masjid agar terlihat rapi dan bersih. Berdasarkan cuplikan dialog di atas dapat disimpulkan bahwa terdapat nilai karakter gotong royong pada episode "Masjid dan Pemuda Punk". Karakter gotong royong adalah karakter yang telah tumbuh dan menjadi bagian hidup masyarakat Indonesia. Dengan gotong royong maka pekerjaan akan mudah selesai. Nilai karakter gotong royong mencerminkan tindakan menghargai semangat kerjasama dan bahu-membahu menyelesaiakn persoalan bersama, menjalin komunikasi dan persahabatan, memberi bantuan/pertolongan pada orangorang yang membutuhkan (Ramdani, 2018). Gotong royong adaah suatu bentuk kerja sama yang dilakukan secara bersama-sama baik di lingkungan sekolah dan masyarakat dalam mencapai tujuan tetentu. Dapat disimpulkan bahwa gotong royong adalah sebuah sikap atau perilaku yang dilakukan secara ikhlas tanpa mengharapkan imbalan apapun. Hal ini dilakukan untuk kepentingan bersama dan bukan dilakuakn di atas kepentingan pribadi.

Nilai karakter intergritas pada episode "Jujur Itu Keren" (https://youtu.be/WQEcsh2eUl4). Dalam cuplikan film dijelaskan bahwa Mona ketahuan berbohong kepada teman-temannya. Mona tidak berkata jujur mengenai bonus yang diberikan babe kepada teman-temannya dan memakannya sendiri di jalan. Diva yang mengetahui hal itu memberikan nasehat kepada Mona agar belajar untuk berkata jujur karena "jujur itu keren". Dari penjelasan tersebut dapat diketahui bahwa dalam episode "Jujur Itu Keren" terdapat nilai karakter Kejujuran. Integritas berarti orang tersebut harus dapat berkata jujur dan bertanggung jawab dalam segala hal. Nilai karakter integritas merupakan nilai yang mendasari perilaku yang didasarkan pada upaya menjadikan dirinya sebagai orang yang selalu dapat dipercaya dalam perkataan, tindakan, dan pekerjaan, memiliki komitmen dan kesetiaan pada nilai-nilai kemanusiaan dan moral (Pasrah et al., 2020). Integritas secara aktif terinternalisasi sebagai rasa ketuhanan dan keseimbangan dalam individu yang menyadari konteks diri dan memiliki keyakinan moral, serta konsisten untuk mewujudkannya kedalam perilaku, tanpa harus merasa malu dan berani untuk menyebarkan keyakinannya (Putri et al., 2021; Sayekti, 2019). Dari penjelasan di atas dapat disimpulkan bahwa nilai karakter integritas merupakan pedoman dasar yang harus dimiliki oleh setiap orang sebagai bentuk perwujudan dirinya sebagai manusia yang jujur dan bertanggung jawab dalam perkataan dan perbuatan.

\section{SIMPULAN DAN SARAN}

Berdasarkan penelitian struktur teks dan nilai karakter yang tekandung dalam sebuah karya sastra film animasi anak Diva The Series Karya Kastari Animation. Struktur teks tersebut meliputi alur, tokoh, karakter, latar tema dan amanat. Selain struktur teks, film animasi Diva The Series juga mengandung nilai pendidikan karakter kemandirian dalam episode "Belajar jualan", nilai karakter religius dalam episode "Pergi tadarus", nilai karakter gotong royong dalam episode "Masjid dan Pemuda Punk", nilai karakter nasionalisme dalam episode "Hari Kartini", dan nilai karakter integritas berupa kejujuran dalam episode "Jujur Itu Keren". Film animasi Diva The series agar dapat menciptakan karya yang lebih baik dan kreatif lagi agar tidak ketinggalan dengan perkembangan zaman. Kedua, untuk seluruh masyarakat Indonesia agar memperbanyak referensi tontonan film yang berkualitas dan mengandung nilai karakter untuk mengatasi lemahnya nilai pendidikan karakter di Indonesia.

\section{DAFTAR PUSTAKA}

Chairiyah. (2017). Implementasi Pendidikan Karakter melalui Nilai-nilai Kearifan Lokal di SD Taman Siswa Jetis Yogyakarta. Jurnal Pendidikan Ke-SD-An, 4(1), 208-215. https://doi.org/10.30738/trihayu.v4i1.2116. 
Christopher, A. E., Waluyanto, H. D., \& Wahyudi, A. T. (2019). Perancangan Board Game Pembelajaran Toleransi Terhadap Perbedaan Pada Pelajaran Ppkn. Jurnal DKV Adiwarna, 2(15), 1-9. http://publication.petra.ac.id/index.php/dkv/article/view/9733.

Dwi pradipta, G. (2017). Strategi Peningkatan Keterampilan Gerak untuk Anak Usia Dini Taman Kanak-Kanak B. Jendela Olahraga, 2(1), 140-147. https://doi.org/10.26877/jo.v2i1.1292.

Hidayah, N. (2015). Penanaman Nilai-nilai Karakter Dalam Pembelajaran Bahasa Indonesia di Sekolah Dasar. Jurnal Pendidikan Dan Pembelajaran Dasar, 2(2). https://doi.org/10.24042/terampil.v2i2.1291.

Ismayani, M. R. (2013). Kreativitas dalam Pembelajaran Literasi Teks Sastra. Semantik, 2(2), 6786.

Khusniati, M. (2014). Model Pembelajaran Sains Berbasis Kearifan Lokal Dalam Menumbuhkan Karakter Konservasi. Indonesian Journal of Conservation, 3(1), 67-74. https://doi.org/10.15294/ijc.v3i1.3091.

Mansyur, A. R. (2020). Dampak COVID-19 Terhadap Dinamika Pembelajaran Di Indonesia. Education and Learning Journal, 1(2), 113. https://doi.org/10.33096/eljour.v1i2.55.

Munawaroh, R. L., \& Prasetyo, S. A. (2019). Nilai Karakter dalam Film Animasi "Horton Hears A Who" Sudut Pandang. Indonesian Values and Character Education Journal, 2(1), 19. https://doi.org/10.23887/ivcej.v2i1.17925.

Pasrah, R., Ganda, N., \& Mulyadiprana, A. (2020). Nilai-Nilai Karakter yang Terdapat dalam Film Animasi Upin dan Ipin Episode "Jembatan IImu." PEDADIDAKTIKA: Jurnal IImiah Pendidikan Guru Sekolah Dasar, 7(3), 152-164. https://ejournal.upi.edu/index.php/pedadidaktika/article/view/28665.

Putri, R., Murtono, M., \& Ulya, H. (2021). Nilai-Nilai Pendidikan Karakter Film Animasi Upin dan Ipin. Jurnal Educatio FKIP UNMA, 7(3), 1253-1263. https://doi.org/10.31949/educatio.v7i3.1401.

Putry, R. (2019). Nilai Pendidikan Karakter Anak Di Sekolah Perspektif Kemendiknas. Gender Equality: International Journal of Child and Gender Studies, 4(1), 39. https://doi.org/10.22373/equality.v4i1.4480.

Rachmawati, W., Benty, D. D. N., \& Sumarsono, R. B. (2018). Budaya Sekolah Berbasis Ketarunaan Dalam Pembentukan Karakter Peserta Didik. Jurnal Administrasi Dan Manajemen Pendidikan, 1, 410-418. https://doi.org/10.17977/um027v1i42018p410.

Ramdani, E. (2018). Model Pembelajaran Kontekstual Berbasis Kearifan Lokal sebagai Penguatan Pendidikan Karakter. Jupiis: Jurnal Pendidikan IImu-IImu Sosial, 10(1), 1. https://doi.org/10.24114/jupiis.v10i1.8264.

Sayekti, O. M. (2019). Film Animasi "Nussa dan Rara Episode Baik Itu Mudah" sebagai Sarana Penanaman Karakter pada Anak Usia Dini. Jurnal Pendidikan Anak, 8(2), 164-171. https://doi.org/10.21831/jpa.v8i2.29093.

Tanto, O. D., Hapidin, H., \& Supena, A. (2019). Penanaman Karakter Anak Usia Dini dalam Kesenian Tradisional Tatah Sungging. Jurnal Obsesi : Jurnal Pendidikan Anak Usia Dini, 3(2), 337-345. https://doi.org/10.31004/obsesi.v3i2.192.

Utomo, C. B., \& Muntholib, A. (2018). Implementasi Pendidikan Karakter dalam Membentuk Sikap dan Perilaku Sosial Peserta Didik Melalui Pembelajaran Sejarah di SMA PGRI 1 Pati Tahun Pelajaran 2017/2018. Indonesian Journal of History Education, 6(1), 1-13. https://journal.unnes.ac.id/sju/index.php/ijhe/article/view/27332.

Vykhrushch, V. O., Romanyshyna, L. M., Pehota, O. M., Shorobura, I. M., \& Kravets, R. A. (2020). The efficiency of training a teacher at higher education institutions of different profiles. European Journal of Educational Research, 9(1), 67-78. https://doi.org/10.12973/eujer.9.1.67.

We, A. Y., \& Fauziah, P. Y. (2020). Tradisi Kearifan Lokal Minangkabau "Manjujai" untuk Stimulasi Perkembangan Anak Usia Dini. Jurnal Obsesi : Jurnal Pendidikan Anak Usia Dini, 5(2), 1339-1351. https://doi.org/10.31004/obsesi.v5i2.660.

Yuniarni, D. (2016). Peran Paud Dalam Mengoptimalkan Tumbuh Kembang Anak Usia Dini Demi Membangun Masa Depan Bangsa. Jurnal Visi IImu Pendidikan, 8(1), 1-13. https://doi.org/10.26418/jvip.v8i1.27370. 